\title{
Nutrient evaluation of the seed, pulp, flesh, and peel of spaghetti squash
}

\author{
Yang $\mathrm{LI}^{1}$, Hosahalli S RAMASWAMY ${ }^{2}$, Jiajia $\mathrm{LI}^{1}$, Yuexia $\mathrm{GAO}^{1}$, Chenyu YANG ${ }^{1}$, Xiaorong ZHANG ${ }^{3}$, \\ Ahmad IRSHAD $^{4}$, Yamei REN ${ }^{1 *}$ (D)
}

\begin{abstract}
The objective of this study was to evaluate the chemical composition of the seed, pulp, flesh, and peel of spaghetti squash (SS) in order to assess its nutritional and health benefits. Results showed that several of the following nutrients were found in significant amounts in different parts of SS: fat, protein, amino acids like cystine, vitamins, and mineral elements like selenium in the seeds; vitamin $\mathrm{C}$ and trigonelline in the flesh; and calcium and tartronic acid in the peel. Analysis of the index of nutritional quality for $\mathrm{Ca}, \mathrm{P}, \mathrm{K}, \mathrm{Na}, \mathrm{Fe}, \mathrm{Zn}, \mathrm{V}_{\mathrm{A}}, \mathrm{V}_{\mathrm{B1}}, \mathrm{V}_{\mathrm{B} 2}, \mathrm{~V}_{\mathrm{C}}$, non-fiber carbohydrate, protein, fat, and dietary fiber revealed that the SS seed, pulp, flesh, and peel are excellent sources of protein, dietary fiber, vitamin $\mathrm{C}$, and minerals. The seed was a source of several nutritional components that could improve the growth and development in children, the flesh contained components that help to maintain blood glucose stability and assist hypoglycemic function, and the peel contributes calcium and weightloss products to help increase bone density and reduce weigh respectively. These results suggest that spaghetti squash makes a source of valuable nutraceuticals.
\end{abstract}

Keywords: spaghetti squash; nutritional composition; nutritional value; index of nutritional quality; nutraceutical.

Practical Application: The manuscript summarizes the potential of the seed, pulp and peel of spaghetti squash to be commercially used for nutraceutical applications and to be incorporated in food formulations to improve health, which helps to develop value-added nutrition products.

\section{Introduction}

Spaghetti squash (SS) (Cucurbita pepo L. subsp. pepo) is a variety of zucchini, and its shape resembles that of a cantaloupe with a golden peel and its seed is similar to that of a pumpkin. It is also named as 'shark fin melon' because its natural flesh resembles shark's fin. SS weighs from 2 to $4 \mathrm{~kg}$ and can be distinguished by its four parts, namely the flesh, peel, pulp, and seed, which account for $60 \%, 30 \%, 7 \%$, and $3 \%$ of the total weight, respectively (Zhuang, 2019; Guo, 2020). SS is an excellent source of high-quality protein, dietary fiber, vitamins, minerals, carotenoids, particularly $\beta$-carotene, foil acid and other components that are beneficial to health (Han et al., 2011; Wadas et al., 2012; Wadas \& Borysiak-Marciniak, 2016). SS also contains functional compounds such as trigonelline and tartronic acid, which are believed to have a protective role against many diseases, including hyperlipemia, diabetes, and cancer, and a role in weight loss (Sun et al., 2013; Xu et al., 2016; Mohamadi et al., 2018; Hu et al., 2019). The protein in SS is considered to be of high-quality because of its good amino acid composition. Moreover, SS contains a high amount of lysine, which is often lacking in other vegetables and plant crops (Han et al., 2011). Food supplements and nutraceuticals are considered to be high value when derived from food sources. The term nutraceuticals usually refers to products available in the market that has either not been properly evaluated for their beneficial health effects (Amin et al., 2019) or contain them in excess amounts. SS is a rich source of nutrients and could be a potential source of nutraceuticals.

Some researchers have discussed the effect of agronomic factors of SS have been shown to have a significant effect on its chemical composition of various species of squash, although there are few studies concerning spaghetti squash. So far, the main research is to compare the contents of sugar, carotenoid, retinol and vitamin C in the fruit of several varieties of spaghetti spaghetti (Beany et al. 2003; Wadas \& Kalinowski, 2010; Wadas et al. 2012; Wadas \& Borysiak-Marciniak, 2016), and there has been relatively little attention paid to mineral components, amino acid, functional nutrients (Kulczyński \& Gramza-Michalowska, 2019). In China, SS is grown mainly in Shanghai, Jiangsu, Shandong, and Anhui provinces. Among them, the Sixian County of Anhui Province employs a scientific planting method, which has contributed to an increase in the production, quality, and storage time of SS. SS is distributed widely throughout the county and country, with 
its local population receiving significant economic benefits from the supply of its crops of SS. However, most SSs are consumed as fresh vegetable cuisine and have a low industrial processing rate. Therefore, research and development into SSs as a nutritional and stable food component suitable for the dietary habits of the Chinese population will be of profound significance for its economic dominance.

The seed, pulp, flesh, and peel of SSs can be used as resources for a large number of applications; however, most of these parts are discarded except for the flesh. Moreover, research on SS has only focused on molecular biology, planting technology, and field diseases. Very few studies exist with regard to the nutritional evaluation of SS. Han et al. (2011) concluded that the flesh of SS, which contains major nutrient components, is degraded by boiling. Research on the nutritional value of other parts of the SS plant in China is almost not existent. Furthermore, awareness of nutritional importance of SS is very scarce to the general population and it is mainly consumed locally where it is grown. In addition, no research has been conducted to analyze its complete nutrient profile. Comprehensive studies on the nutritional benefits of SS are needed and will help to better assess its importance to the well-being of populations that consume it. Therefore, the aim of this study was to evaluate nutrient profile focusing on both functional and basic nutrient contents, mineral and vitamin contents, amino acid composition, and index of nutritional quality (INQ) of different parts of SS. This study would provide useful information on the potential utilization of SS in formulation of health products.

\section{Material and methods}

\subsection{Raw material}

Spaghetti squash used in this study was collected at the experimental station of Sixian Hong Cheng Aerospace Science and Agriculture Development Co., Ltd. (Anhui, China). A total of 30 spaghetti squash of "Paiza No. 1" were selected to test. SS was washed with running water to remove dust and mud, and then rinsed first with deionized water and finally with ultrapure water (South China Hi-tech Environmental Protection Technology Co., Ltd). The peel surface was dried using a filter paper, and the seed, pulp, flesh, and peel were separated from the SS.

\subsection{Functional nutrients analysis}

\section{Trigonelline}

Trigonelline content was determined using a high-performance liquid chromatography (HPLC) method (LC-20A, shimadzu, Japan) (Xu et al., 2010). All parts of the SS were dried, powdered, and put into a Soxhlet extractor. Anhydrous ether (analytically pure) was added and reflexed continuously for $12 \mathrm{~h}$ until it volatilized entirely. After that, $5 \mathrm{~g}$ of defatted powder was mixed with $100 \mathrm{~mL}$ of $70 \%$ ethanol solution, and the mixture was extracted with in an ultrasound system for 7 min (JingQi Co., Ltd., UC-120EB, Shanghai, China), filtered, dissolved in chromatographic methanol, and fixed to a volume of $25 \mathrm{~mL}$. The solution was filtered through a $0.45 \mu \mathrm{m}$ membrane filter (Solarbio Science \& Technology Co., Ltd., Beijing, China), after which the filtrate was immediately extracted for evaluation.
The chromatographic conditions were set as follows: a Shimadzu WondaSil- $\mathrm{C}_{18}$ column $(4.6 \mathrm{~mm} \times 150 \mathrm{~mm}, 5 \mu \mathrm{m})$ maintained at room temperature was used, and chromatographic separation was performed with $0.40 \mathrm{mmol} / \mathrm{L}$ aqueous solution of phosphoric acid (chromatographic purity, $\mathrm{pH}$ 3.2) as the mobile phase at a flow rate of $0.6 \mathrm{~mL} / \mathrm{min}$. The injection volume was $10 \mu \mathrm{L}$. The detection wavelength was set at $265 \mathrm{~nm}$, and the following linear regression equation for trigonelline was used: $y=22052 x-57355\left(R^{2}=0.9994\right)(\mathrm{Xu}$ et al., 2010).

\section{Tartronic acid}

Tartronic acid content was also determined using a HPLC method (LC-20A, shimadzu, Japan) (Xu et al., 2016). All parts of SS were squeezed (V82, Joyoung, China), and $5 \mathrm{~g}$ of the juice was placed into a $100 \mathrm{~mL}$ beaker; $400 \mathrm{~mL}$ of $50 \%$ ethanol was added, and the mixture was transferred into a $500 \mathrm{~mL}$ volumetric flask, mixed evenly, and left to stand for $30 \mathrm{~min}$ at room temperature. The filtrate was then filtered and transferred into a volumetric flask. Afterward, $30 \mathrm{~mL}$ of filtrate was placed into a centrifuge tube to be centrifuged for $10 \mathrm{~min}$ at $4000 \mathrm{rpm}$ (Anhui ustc zonkia scientific instruments Co., LTD., HC-3018R, China). After centrifugation, the supernatant was transferred into a $100 \mathrm{~mL}$ conical flask, in which $1 \%$ calcium carbonate was added and the $\mathrm{pH}$ was adjusted to 7.0 (Shanghai electronic scientific instrument Co., LTD., PHS-3E, China). The reaction was observed in the filtrate, the filtrate was filtered, and the precipitate was collected after the reaction was balanced. Subsequently, $3 \mathrm{~mL}$ of $1 \%$ calcium chloride solution was added to the filtrate, stood for $30 \mathrm{~min}$, after which it was filtered and the supernatant discarded. The two precipitation materials were mixed, added with $5 \mathrm{~mL}$ of deionized water, mixed again, and then washed for $10 \mathrm{~min}$. After $30 \mathrm{~min}$, the supernatant was discarded. The precipitate was titrated with $0.5 \mathrm{~mol} / \mathrm{L}$ diluted sulfuric acid until it was dissolved entirely, left to stand for $4 \mathrm{~h}$, and centrifuged. It was then concentrated with a rotary evaporator (Shanghai Shensheng Technology Co., LTD., R-205, China), dissolved in ethanol and adjusted to a volume of $10 \mathrm{~mL}$, and passed through a $0.45 \mu \mathrm{m}$ membrane filter (Solarbio Science \& Technology Co., Ltd., Beijing, China), after which the filtrate was immediately extracted for evaluation.

The chromatographic conditions were set as follows: a Shimadzu WondaSil-C18 column $(4.6 \mathrm{~mm} \times 150 \mathrm{~mm}, 5 \mu \mathrm{m})$ kept at an ambient temperature was used, and chromatographic separation was performed with $0.1 \%$ aqueous solution of sodium sulfate as the mobile phase at a flow rate of $1 \mathrm{~mL} / \mathrm{min}$. The injection volume was $10 \mu \mathrm{L}$. The detection wavelength was set at $215 \mathrm{~nm}$, and the following linear regression equation for Tartronic acid was used: $y=2755.8 x+101053\left(R^{2}=0.9992\right)(\mathrm{Xu}$ et al., 2016).

\subsection{Basic nutrients}

Moisture, soluble sugar, reducing sugar, fat, protein, and dietary fiber contents in the seed, pulp, flesh, and peel of SS were determined. Moisture ( $\mathrm{g} / 100 \mathrm{~g}$ FW) was assessed using the direct drying method (GB 5009.3-2016); soluble sugars (g/100 g FW) was assessed using the 3,5 dinitrosalicylic acid colorimetric method, (NY/T 2742-2015) (Chang et al., 2017); reducing sugars, using the titration method (GB 5009.7-2016); fat (g/100 g FW) content was determined by Association of Analytical 
Chemists (2000) AOAC method 960.39; proteins (g/100 g FW), using the micro-Kjeldahl method (AOAC method 976.05); and dietary fiber was determined by the AOAC method 991.43; SS samples were also tested for ash content before and after heat treatment $\left(550^{\circ} \mathrm{C}\right.$ for $\left.12 \mathrm{~h}\right)$. Non-fiber Carbohydrate content was calculated by subtracting the sum of ash, fat, protein, and dietary fiber contents from 100.

\subsection{Vitamins}

Vitamin $A\left(V_{A}\right)$, vitamin $B_{1}\left(V_{B 1}\right)$, vitamin $B_{2}\left(V_{B 2}\right)$, and vitamin $\mathrm{C}\left(\mathrm{V}_{\mathrm{C}}\right)$ contents in different parts of SS were assessed using HPLC methods (GB 5009.82-2016, GB 5009.84-2016, GB 5009.85-2016, and GB 5009.86-2016) (Sun et al., 2021).

\subsection{Amino acids}

Amino acid contents in different parts of SS were determined in accordance with the China National Standard (GB 5009.32016). Amino acids with taste properties were calculated as follows: delicate taste class, by the amount of glutamate and aspartic acid; sweet taste class, by the amount of alanine, glycine, serine, and proline; and the aromatic, by the amount of tyrosine and phenylalanine. The amino acid composition appropriate for adult human consumption (Food And Agriculture Organization of The United Nations/World Health Organization, 1991) was used to estimate the amino acid score (AAS). The recommended levels of individual amino acids ( $\mathrm{g}$ amino acid/100 $\mathrm{g}$ protein) were as follows: valine, $5 \mathrm{~g} / 100 \mathrm{~g}$; methionine +cystine, $3.5 \mathrm{~g} / 100 \mathrm{~g}$; isoleucine, $4 \mathrm{~g} / 100 \mathrm{~g}$; leucine, $7 \mathrm{~g} / 100 \mathrm{~g}$; phenylalanine + tyrosine, $6 \mathrm{~g} / 100 \mathrm{~g}$; lysine, $5.5 \mathrm{~g} / 100 \mathrm{~g}$; and threonine, $4 \mathrm{~g} / 100 \mathrm{~g}$ (Liu et al., 2017).

\subsection{Mineral elements}

Calcium $(\mathrm{Ca})$, potassium $(\mathrm{K})$, sodium $(\mathrm{Na})$, iron $(\mathrm{Fe})$, zinc $(\mathrm{Zn})$, and selenium $(\mathrm{Se})$ contents were determined using the ICP-MS method i (GB 5009.268-2016), and phosphorus (P) was determined using the molybdenum blue spectrophotometric method (GB 5009.87-2016) (Sun et al., 2021).

\subsection{Index of nutritional quality (INQ)}

A method utilizing the INQ to quantitatively evaluate the nutritional quality of food has been proposed by Sun et al. (2014). The INQ was defined as the ratio of the amount of nutrients present in the food to the amount of total calories in the food and was used to evaluate the specific nutritional contribution of the food to the diet. Using the Chinese Dietary Reference Intakes (DRIs) as a standard, the INQ was calculated according to the following equation: $\mathrm{INQ}=$ (amount of nutrient per $100 \mathrm{~g} /$ Chinese DRI of that nutrient)/(calories in $100 \mathrm{~g} /$ energy reference intake) (Xu et al., 2017), where the Chinese DRIs for protein, fat, non-fiber carbohydrate, and fiber are $60 \mathrm{~g}, 60 \mathrm{~g}$, $300 \mathrm{~g}$, and $25 \mathrm{~g}$, respectively; the Chinese DRIs for $\mathrm{Ca}, \mathrm{P}, \mathrm{K}, \mathrm{Na}$, $\mathrm{Fe}$, and $\mathrm{Zn}$ are $800 \mathrm{mg}, 700 \mathrm{mg}, 2000 \mathrm{mg}, 1500 \mathrm{mg}, 15 \mathrm{mg}$, and $10 \mathrm{mg}$, respectively; the Chinese DRIs for $\mathrm{V}_{\mathrm{A}}, \mathrm{V}_{\mathrm{B1}}, \mathrm{V}_{\mathrm{B} 2}$, and $\mathrm{V}_{\mathrm{C}}$ are $750 \mathrm{mg}, 1.3 \mathrm{mg}, 1.3 \mathrm{mg}$, and $100 \mathrm{mg}$, respectively; and the average energy intake is $2000 \mathrm{kcal}$ (Liu et al., 2017).

\subsection{Statistical analysis}

All data were expressed as averages and standard deviations of three replicates and statistically analyzed using analysis of variance. Significant differences in the contents of basic nutrients, vitamins, amino acids and minerals among the four parts of seed, pulp, flesh and peel were determined by Tukey's test using SPSS software $(p<0.05)$.

\section{Results and discussion}

\subsection{Functional nutrients analysis}

Trigonelline is an alkaloid that has some properties such as antioxidant, anti-inflammatory, cholesterol-reducing, nerveprotecting, and blood glucose-stabilizing (Gaddam et al., 2015; Anwar et al., 2018; Khalili et al., 2018; Pravalika et al., 2019). In this study, the flesh of SS had the highest trigonelline content, whereas the seed had the lowest trigonelline content (Table 1). The trigonelline content of the flesh was about 17 times that of fresh chestnuts (Servillo et al., 2016) and 1.25 times that of pumpkin pulp (Xu et al., 2010) $(p<0.05)$. The next highest trigonelline concentration was in the pulp, which was similar to that found in pumpkins and wax gourds. Therefore, SS can be a recommended as a preferred vegetable for patients with diabetes problems.

Tartronic acid, on the other hand, is a small molecular weight organic acid that can inhibit the transformation of sugars into fat, prevent the accumulation of fat in the body, and reduce weight (Sun et al., 2013; Xu et al., 2016). As shown in Table 1, tartronic acid exhibited a significant variation in the content among different parts of SS, and the content of tartronic acid in the peel was 30 times that in the seed, 1.4 times that in the pulp, and 2 times that in the flesh $(p<0.05)$. Therefore, SS can be a preferred vegetable for people with obesity.

\subsection{Basic nutrients}

The basic nutrients (moisture, non-fiber carbohydrate, soluble sugars, reducing sugars, fat, protein, and dietary fiber) of the seed, pulp, flesh, and peel of SS were analyzed are shown in Table 2, and the basic nutrient composition varied in different parts of SS.

The moisture contents of the pulp, flesh, and peel were quite similar, up to $95 \mathrm{~g} / 100 \mathrm{~g}$ (fresh weight basis), and were similar to those in watermelon (Cecilio et al., 2018), but higher than those in Kurt pear (Pan et al., 2019). As the flesh had high moisture

Table 1. Functional nutrient composition of the different parts of spaghetti squash (mg/100 g).

\begin{tabular}{ccc}
\hline Position & Trigonelline (dry basis) & Tartronic acid (fresh basis) \\
\hline Seed & $12.8 \pm 0.275^{\mathrm{c}}$ & $0.283 \pm 0.048^{\mathrm{d}}$ \\
Pulp & $18.6 \pm 0.486^{\mathrm{b}}$ & $6.10 \pm 0.202^{\mathrm{b}}$ \\
Flesh & $23.0 \pm 0.639^{\mathrm{a}}$ & $4.11 \pm 0.225^{\mathrm{c}}$ \\
Peel & $14.5 \pm 0.224^{\mathrm{b}}$ & $8.54 \pm 0.123^{\mathrm{a}}$
\end{tabular}

Note: Data are expressed as means \pm standard deviation. $a, b, c$, and $d$ each represent the significant difference in content of the same nutrient among the different parts of spaghetti squash $(p<0.05)$. The number of three replicates used for calculation of means and standard deviation values. 
content and is considered palatable and crisp, it is suitable for use as fresh food; however, its high moisture content relatively shortens its storage time. The moisture content of the seeds was the lowest, at only $43.4 \mathrm{~g} / 100 \mathrm{~g}$, the low moisture content makes it ideal for processing and drying into dried goods.

The amounts of non-fiber carbohydrates, soluble sugars, and reducing sugars in the flesh were significant higher than other parts $(p<0.05)$, but they were lower than those in mango, pineapple, litchi, and other tropical fruits (Septembre-Malaterre et al., 2016). The soluble sugar content of the flesh was also lower than in pumpkin, sweet potato, and onion (Lebot et al., 2013). Considering that different dietary non-fiber carbohydrate levels can lead to different blood glucose responses, it is important to understand the non-fiber carbohydrate profile of SS from the perspective of nutritional status. Thus, SS can be the preferred food for people with diabetes.

Fats and proteins are the primary materials that make up cells, tissues and organs, and have the function of regulating the body (de Boer and Aiking, 2019). The amounts of fat and protein in the seeds of SS were remarkably high $(p<0.05)$ and were approximately 36-, 40-, and 44-fold higher, on average, than those of the pulp, flesh, and peel, respectively, although the difference was not significant for the pulp and peel parts $(p>0.05)$. Therefore, consumption recommendation of the protein-rich seed of SS can be advisable to counter protein energy malnutrition, which is common in some regions in China. Meanwhile, the pulp, flesh, and peel of SS showed to be poor sources of fat and thus can be useful as more suitable staple foods for people with obesity and for preventing cardiovascular diseases (Howard et al., 2018; Yu et al., 2018). Our findings regarding the moisture, non-fiber carbohydrate, and protein contents of the SS flesh were consistent with those reported by Han et al. (2011) for Korean SS (Cucurbita pepo) flesh.

Proper intake of dietary fiber can promote digestion and reduce cholesterol content in humans (Causey et al., 2000; Eduardo
Garcia-Amezquita et al., 2018). In this study, the dietary fiber content of SS ranged from 0.630 (pulp) to 26.5 (seed) g/100 g. Therefore, SS can be a good source of dietary fiber for the human body, and its consumption may prevent gastrointestinal diseases to a certain extent (Yang et al., 2021; Croisier et al., 2021).

\subsection{Vitamins}

Table 3 presents the vitamin content of different parts of SS. The vitamin contents of the seed, flesh, and peel from the highest to the lowest value were in the order $\mathrm{V}_{\mathrm{C}}>\mathrm{V}_{\mathrm{A}}>\mathrm{V}_{\mathrm{B} 1}>\mathrm{V}_{\mathrm{B} 2}$, while those of the pulp were in the order $\mathrm{V}_{\mathrm{C}}>\mathrm{V}_{\mathrm{B} 1}>\mathrm{V}_{\mathrm{A}}>\mathrm{V}_{\mathrm{B} 2}$. In addition, the contents of vitamins in seed were significantly variation from that in pulp, flesh, and peel of SS.

Therefore, the $\mathrm{V}_{\mathrm{C}}$ content of the seed, flesh, and peel were similar, while the $\mathrm{V}_{\mathrm{C}}$ content of the pulp was the least; these $\mathrm{V}_{\mathrm{C}}$ contents were about 1.3 times, 0.3 times, and 6 times higher than those of the seed, pulp, and peel part of the hybrid variety of pumpkin, respectively $(p<0.05)$ (Amin et al., 2019). The $\mathrm{V}_{\mathrm{C}}$ content of the flesh of the Chinese SS was also higher than that of the commonly consumed Korean SS $(p<0.05)$ (Han et al., 2011). Generally, these extreme variations in vitamin composition may be attributed to the geographical differences in the plant variety, planting period, and farming method of SS worldwide. $\mathrm{V}_{\mathrm{C}}$ is important in wound healing and prevention of scurvy and can prevent nitrates from turning into carcinogenic nitrites in the digestive tract (Dorafshani et al., 2018).

The $\mathrm{V}_{\mathrm{A}}$ and $\mathrm{V}_{\mathrm{B} 2}$ contents of the seed were higher than those of the other three parts, being approximately $3.5,3.5,3$, and 3, 8, and 3-fold higher than those of pulp, flesh, and peel, respectively $(p<0.05)$. The $\mathrm{V}_{\mathrm{B} 1}$ content of the pulp was approximately $1-$, 8 -, and 7 -fold higher than that of the seed, flesh, and peel, respectively $(p<0.05)$. However, different parts of SS tested here could be considered as less abundant sources of $\mathrm{V}_{\mathrm{A}}, \mathrm{V}_{\mathrm{B1}}$, and $\mathrm{V}_{\mathrm{B} 2}$. At present, most developing countries have difficulty producing vitamin-rich food due to inadequate agricultural systems, which

Table 2. Basic nutrient composition of the different parts of spaghetti squash ( $\mathrm{g} / 100 \mathrm{~g}$ of fresh matter).

\begin{tabular}{ccrrrrrr}
\hline Position & Moisture & $\begin{array}{c}\text { Non-fiber } \\
\text { carbohydrate }\end{array}$ & Soluble sugars & Reducing sugars & Fat & Protein & Dietary fiber \\
\hline Seed & $43.4 \pm 0.326^{\mathrm{c}}$ & $3.66 \pm 0.003^{\mathrm{b}}$ & $1.50 \pm 0.003^{\mathrm{b}}$ & $1.01 \pm 0.003^{\mathrm{d}}$ & $18.5 \pm 0.889^{\mathrm{a}}$ & $21.9 \pm 0.107^{\mathrm{a}}$ & $26.5 \pm 0.997^{\mathrm{a}}$ \\
Pulp & $95.9 \pm 0.386^{\mathrm{a}}$ & $3.45 \pm 0.001^{\mathrm{c}}$ & $0.783 \pm 0.002^{\mathrm{d}}$ & $1.10 \pm 0.003^{\mathrm{c}}$ & $0.330 \pm 0.020^{\mathrm{b}}$ & $1.30 \pm 0.014^{\mathrm{b}}$ & $0.630 \pm 0.020^{\mathrm{c}}$ \\
Flesh & $96.0 \pm 0.344^{\mathrm{a}}$ & $4.05 \pm 0.003^{\mathrm{a}}$ & $1.58 \pm 0.003^{\mathrm{a}}$ & $3.35 \pm 0.002^{\mathrm{a}}$ & $0.460 \pm 0.020^{\mathrm{b}}$ & $0.524 \pm 0.005^{\mathrm{c}}$ & $1.59 \pm 0.010^{\mathrm{bc}}$ \\
Peel & $94.6 \pm 0.363^{\mathrm{b}}$ & $3.05 \pm 0.003^{\mathrm{d}}$ & $1.14 \pm 0.002^{\mathrm{c}}$ & $2.58 \pm 0.002^{\mathrm{b}}$ & $0.253 \pm 0.015^{\mathrm{b}}$ & $1.41 \pm 0.008^{\mathrm{b}}$ & $2.50 \pm 0.066^{\mathrm{b}}$ \\
\hline
\end{tabular}

Note: Data are expressed as means \pm standard deviation in $\mathrm{g} / 100 \mathrm{~g}$ of fresh matter. $\mathrm{a}, \mathrm{b}, \mathrm{c}$, and $\mathrm{d}$ each represent the significant difference in content of the same nutrient among the different parts of spaghetti squash $(p<0.05)$. The number of three replicates used for calculation of means and standard deviation values.

Table 3. Vitamin contents of the different parts of spaghetti squash (in $\mathrm{mg} / 100 \mathrm{~g}$ of fresh matter).

\begin{tabular}{ccccc}
\hline Position & $\mathrm{V}_{\mathrm{A}}$ & $\mathrm{V}_{\mathrm{B} 1}$ & $\mathrm{~V}_{\mathrm{B} 2}$ & $\mathrm{~V}_{\mathrm{C}}$ \\
\hline Seed & $0.283 \pm 0.001^{\mathrm{a}}$ & $0.154 \pm 0.000^{\mathrm{b}}$ & $0.087 \pm 0.000^{\mathrm{a}}$ & $13.8 \pm 0.055^{\mathrm{b}}$ \\
Pulp & $0.083 \pm 0.000^{\mathrm{c}}$ & $0.166 \pm 0.006^{\mathrm{a}}$ & $0.026 \pm 0.000^{\mathrm{c}}$ & $6.43 \pm 0.002^{\mathrm{c}}$ \\
Flesh & $0.084 \pm 0.001^{\mathrm{c}}$ & $0.020 \pm 0.000^{\mathrm{c}}$ & $0.011 \pm 0.000^{\mathrm{d}}$ & $15.1 \pm 0.483^{\mathrm{a}}$ \\
Peel & $0.089 \pm 0.001^{\mathrm{b}}$ & $0.023 \pm 0.001^{\mathrm{c}}$ & $0.031 \pm 0.000^{\mathrm{b}}$ & $15.1 \pm 0.075^{\mathrm{a}}$ \\
\hline
\end{tabular}

Note: Data are expressed as means \pm standard deviation. $a, b, c$, and d each represent the significant difference in content of the same nutrient among the different parts of spaghetti squash $(p<0.05)$. The number of three replicates used for calculation of means and standard deviation values. $\mathrm{V}_{\mathrm{A}}=$ vitamin $\mathrm{A} ; \mathrm{V}_{\mathrm{B} 1}=$ vitamin $\mathrm{B} 1 ; \mathrm{V}_{\mathrm{B} 2}=$ vitamin $\mathrm{B} 2 ; \mathrm{V}_{\mathrm{C}}=$ vitamin $\mathrm{C}$. 
can lead to an increased risk of diseases caused by insufficient vitamin intake (Bouis, 2018). Although the pulp and peel of SS are usually discarded in China, this study observed that these parts of SS were rich in $\mathrm{V}_{\mathrm{C}}$, and can therefore increase people's $\mathrm{V}_{\mathrm{C}}$ intake in the long term.

\subsection{Amino acid content}

Protein can only be absorbed and utilized in the human body when it is broken down into amino acids. In addition, the different compositions of amino acid in food determine their flavor. Table 4 reports the amino acid contents of different parts of SS.

In this study, 17 types of amino acids needed by the human body were detected in SS, including all the essential amino acids (EAAs) except for tryptophan. Among them, aspartic acid and glutamic acid had the highest content in different parts of SS. Both aspartic acid and glutamic acid are amino acids that give protein its acidic characteristics (Kaur et al., 2017). Moreover, the contents of most amino acids in SS, such as aspartic acid, glutamic acid, arginine, proline, serine, and leucine, were higher than those in pumpkin and zucchini (Apostol et al., 2018; Corleto et al., 2019). The abundance of these amino acids is rare in fruits and vegetables. The results in Table 4 also indicate that the total amino acid (TAA) and EAA contents were highest in the seeds, followed by the peel and pulp of SS. The seeds also contained cysteine, which was not found in the other three parts. The AAS ranged from $2.487 \%$ (flesh) to $3.646 \%$ (peel), the sum of phenylalanine and tyrosine was the highest, while the amount of methionine and cystine was the lowest. Therefore, methionine and cystine are the first-limiting amino acids in SS.

The taste properties of the amino acids in SS are shown in Table 4. The contents of delicate taste class of amino acid (glutamate and aspartic acid) in the seed, pulp, flesh, and peel of SS were about $83,14,6$, and 13 times significantly higher than those of zucchini $(p<0.05)$ (Corleto et al., 2019). The contents of sweet taste class of amino acid (alanine, glycine, serine, and proline) in the seed, pulp, flesh, and peel of SS were about 185-, 11-, 5-, and 16-fold higher than those of celery $(p<0.05)$ (Corleto et al., 2019).

Table 4. Amino acid contents of the different parts of spaghetti squash (g/100 g of fresh matter).

\begin{tabular}{|c|c|c|c|c|}
\hline & Seed & Pulp & Flesh & Peel \\
\hline \multicolumn{5}{|c|}{ Essential and semi-essential amino acids } \\
\hline Lysine & $0.390 \pm 0.010^{\mathrm{a}}$ & $0.038 \pm 0.002^{\mathrm{b}}$ & $0.012 \pm 0.001^{\mathrm{c}}$ & $0.049 \pm 0.001^{\mathrm{b}}$ \\
\hline Methionine & $0.167 \pm 0.006^{\mathrm{a}}$ & $0.005 \pm 0.001^{\mathrm{b}}$ & $0.001 \pm 0.001^{\mathrm{b}}$ & $0.005 \pm 0.001^{\mathrm{b}}$ \\
\hline Threonine & $0.290 \pm 0.010^{\mathrm{a}}$ & $0.021 \pm 0.001^{\mathrm{bc}}$ & $0.009 \pm 0.001^{\mathrm{c}}$ & $0.028 \pm 0.001^{\mathrm{b}}$ \\
\hline Isoleucine & $0.323 \pm 0.006^{\mathrm{a}}$ & $0.023 \pm 0.001^{c}$ & $0.008 \pm 0.001^{\mathrm{d}}$ & $0.032 \pm 0.001^{\mathrm{b}}$ \\
\hline Leucine & $0.653 \pm 0.006^{\mathrm{a}}$ & $0.036 \pm 0.001^{\mathrm{c}}$ & $0.012 \pm 0.001^{\mathrm{d}}$ & $0.044 \pm 0.001^{\mathrm{b}}$ \\
\hline Phenylalanine & $0.513 \pm 0.001^{\mathrm{a}}$ & $0.031 \pm 0.000^{c}$ & $0.011 \pm 0.001^{\mathrm{d}}$ & $0.041 \pm 0.001^{\mathrm{b}}$ \\
\hline Valine & $0.403 \pm 0.006^{\mathrm{a}}$ & $0.027 \pm 0.001^{\mathrm{c}}$ & $0.010 \pm 0.001^{\mathrm{d}}$ & $0.038 \pm 0.001^{\mathrm{b}}$ \\
\hline Histidine & $0.213 \pm 0.006^{\mathrm{a}}$ & $0.015 \pm 0.001^{\mathrm{b}}$ & $0.005 \pm 0.001^{\mathrm{c}}$ & $0.020 \pm 0.001^{\mathrm{b}}$ \\
\hline Arginine & $1.40 \pm 0.025^{\mathrm{a}}$ & $0.095 \pm 0.003^{\mathrm{b}}$ & $0.027 \pm 0.001^{\mathrm{c}}$ & $0.093 \pm 0.002^{\mathrm{b}}$ \\
\hline \multicolumn{5}{|c|}{ Nonessential amino acids } \\
\hline Glutamic acid & $1.54 \pm 0.030^{\mathrm{a}}$ & $0.229 \pm 0.004^{\mathrm{b}}$ & $0.071 \pm 0.001^{c}$ & $0.198 \pm 0.003^{b}$ \\
\hline Alanine & $0.417 \pm 0.006^{\mathrm{a}}$ & $0.025 \pm 0.001^{\mathrm{c}}$ & $0.010 \pm 0.001^{\mathrm{d}}$ & $0.038 \pm 0.001^{\mathrm{b}}$ \\
\hline Glycine & $0.473 \pm 0.006^{\mathrm{a}}$ & $0.028 \pm 0.001^{\mathrm{b}}$ & $0.009 \pm 0.001^{\mathrm{c}}$ & $0.034 \pm 0.001^{\mathrm{b}}$ \\
\hline Aspartic acid & $0.780 \pm 0.010^{\mathrm{a}}$ & $0.166 \pm 0.001^{b}$ & $0.105 \pm 0.001^{\mathrm{c}}$ & $0.164 \pm 0.001^{b}$ \\
\hline Cystine & $0.120 \pm 0.006$ & ND & ND & ND \\
\hline Proline & $0.700 \pm 0.010^{\mathrm{a}}$ & $0.049 \pm 0.001^{c}$ & $0.016 \pm 0.001^{\mathrm{d}}$ & $0.064 \pm 0.004^{\mathrm{b}}$ \\
\hline Tyrosine & $0.337 \pm 0.012^{\mathrm{a}}$ & $0.024 \pm 0.001^{\mathrm{bc}}$ & $0.012 \pm 0.001^{\mathrm{c}}$ & $0.033 \pm 0.001^{\mathrm{b}}$ \\
\hline Serine & $0.440 \pm 0.010^{\mathrm{a}}$ & $0.033 \pm 0.001^{c}$ & $0.020 \pm 0.001^{c}$ & $0.048 \pm 0.001^{\mathrm{b}}$ \\
\hline Total amino acids & 9.159 & 0.845 & 0.338 & 0.926 \\
\hline \multicolumn{5}{|c|}{ AAS (mg/g) } \\
\hline Valine & 0.368 & 0.414 & 0.382 & 0.538 \\
\hline Methionine + Cystine & 0.374 & 0.111 & 0.054 & 0.101 \\
\hline Isoleucine & 0.368 & 0.440 & 0.383 & 0.565 \\
\hline Leucine & 0.426 & 0.394 & 0.09 & 0.444 \\
\hline Phenylalanine+Tyrosine & 0.645 & 0.702 & 0.732 & 0.872 \\
\hline Lysine & 0.324 & 0.529 & 0.416 & 0.631 \\
\hline Threonine & 0.330 & 0.403 & 0.430 & 0.495 \\
\hline AAS (\%) & 2.835 & 2.993 & 2.487 & 3.646 \\
\hline Delicate taste class & $2.32 \pm 0.036^{\mathrm{a}}$ & $0.396 \pm 0.003^{\mathrm{b}}$ & $0.176 \pm 0.003^{c}$ & $0.362 \pm 0.001^{\mathrm{b}}$ \\
\hline Sweet taste class & $2.03 \pm 0.010^{\mathrm{a}}$ & $0.135 \pm 0.002^{c}$ & $0.056 \pm 0.001^{\mathrm{d}}$ & $0.181 \pm 0.002^{\mathrm{b}}$ \\
\hline Aromatic & $0.847 \pm 0.010^{\mathrm{a}}$ & $0.055 \pm 0.001^{\mathrm{bc}}$ & $0.023 \pm 0.001^{\mathrm{c}}$ & $0.074 \pm 0.001^{\mathrm{b}}$ \\
\hline
\end{tabular}

Note: Data are expressed as means \pm standard deviation. a, b, c, and d each represent the significant difference in content of the same nutrient among the different parts of spaghetti squash $(p<0.05)$. ND, not detected; AAS, amino acid score. The number of three replicates used for calculation of means and standard deviation values. 
High water content and sweetness can improve the palatability of these vegetables, but these may also reduce their shelf-life by promoting fungal infection (Ntuli, 2019). The contents of aromatic of amino acid (tyrosine and phenylalanine) in the seed, pulp, flesh, and peel of SS were approximately $61,4,1.5$, and 5 times higher than those of yellow squash $(p<0.05)$ (Corleto et al., 2019). In addition, the aromatic in these vegetables exist in some peptide chains and are therefore important contributors to antioxidant activity (Zou et al., 2016). The contents of these three types of amino acids according to their taste properties were highest in the seed and lowest in the flesh of SS. The contents of delicate taste class in the pulp were higher than those in the peel, while the contents of sweet taste class and the aromatic in the peel were higher than those in the pulp. Overall, content of delicate taste class of amino acid was the highest, followed by that of sweet taste class. Thus, this study showed that SS contained high-quality amino acids, eating together with other foods to ensure complete absorption of nutrients.

\subsection{Mineral content}

The mineral contents of the seed, pulp, flesh, and peel parts of SS are summarized in Table 5. Minerals are divided into two groups: macroelements and microelements. Microelements are essential nutrients, but their content in the human body is very low. Therefore, the intake of microelements in the diet has a significant influence on human health.

$\mathrm{K}, \mathrm{Ca}, \mathrm{P}$, and $\mathrm{Na}$ are necessary macroelements for human growth and development. $\mathrm{K}$ can stimulate neuromuscular activity and maintain normal nerve and muscle function (Arnold et al., $2019)$. In this study, the amount of $K$ was remarkably high in the seed of SS ( $p<0.05)$, being 2, 2.7, and 2.8 times higher than that of the pulp, flesh, and peel respectively. Moreover, the $\mathrm{K}$ contents of the seed, pulp, flesh, and peel were approximately $2.5,1.3,1$, and 0.9 times that of the peel of Mashui orange ( $p<$ 0.05) (Chen et al., 2018). These results suggest that SS is high in potassium and thus can be consumed regularly to prevent or control high blood pressure, reduce the risks of heart attack and strokes, and reduce the mortality rate of heart diseases (Dogan et al., 2019; Kajanus et al., 2019).

$\mathrm{Ca}$ is an essential element for maintaining the normal physiological function of the human body, and the best source of calcium supplement is diet. The Ca content of the peel was 1.5 times that of the seed, 4 times that of the pulp, and 3 times that of the flesh, whereas the Ca contents of the seed, flesh, and peel were about $8.8,21$, and 38 times that of the indigenous variety of pumpkin, respectively $(p<0.05)$ (Amin et al., 2019).
The Ca contents of the flesh and peel of SS were about 3.7 and 1.27 times that of the pulp and peel parts of the banana respectively (Oyeyinka \& Afolayan, 2019).

$\mathrm{P}$ is one of the main components of nucleic acids and cell membranes, making $\mathrm{P}$ intake also vital for human health. The $\mathrm{P}$ content of SS ranged from 9.95 (flesh) to 589 (seed) $\mathrm{mg} / 100 \mathrm{~g}$, which is higher than that of other common vegetables. This phenomenon indicates that SS could be a rich source of P. In addition, $\mathrm{Ca}$ and $\mathrm{P}$ are essential components of human bones, and low $\mathrm{Ca}$ and $\mathrm{P}$ levels have been associated with osteoporosis and chondropathy. Therefore, regular consumption of SS can effectively prevent osteoporotic fractures and reduce fracture risks in the elderly and the weak (Briffa et al., 2019).

In conclusion, the contents of $\mathrm{P}, \mathrm{K}$ and $\mathrm{Ca}$ in seed of $\mathrm{SS}$ of variety "paiza No.1", "Makaronowa Warszawska" and "Pyza" varieties was similar and these elements in pulp, flesh and peel of SS variety "paiza No.1" were significantly lower than those of "Makaronowa Warszawska" and "Pyza" varieties and both conventionally and organically grown squash in Lithuania $(p<0.05)$ (Wadas \& Borysiak-Marciniak., 2016; Danilchenko., 2002).This indicates that the mineral content of spaghetti squash is affected by soil type, climate condition and geographical location. Meanwhile the contents of $\mathrm{P}, \mathrm{K}$, and $\mathrm{Ca}$ in the four parts of SS were also lower than those of varieties from Israel and the United States (Beany et al., 2002).

The most abundant microelement in SS was $\mathrm{Zn}$, followed by Fe and Se. $\mathrm{Zn}$ is involved in the synthesis of nucleic acids and proteins in the human body. It is an essential component of the adrenocortical hormone and is important for human growth and development. Moreover, $\mathrm{Zn}$ is mainly distributed in the secretory granules of $\beta$-cells in the islets of langerhans, which can promote the crystallization of insulin in the human body and effectively prevent diabetes (Okabe et al., 2018). The Fe, Zn, and $\mathrm{Na}$ contents of SS seeds recorded in this study were higher than those of Cucurbita pepo of the Miranda variety (Kulczyński \& Gramza-Michalowska, 2019), but less than those of the Korean SS reported by Han et al. (2011).

the contents of Fe of variety "paiza No.1" were significantly lower than those of "Makaronowa Warszawska" and "Pyza" varieties $(p<0.05)$, The reason is that compared with the planting time on May 25, the Fe content of the plant fruit sown on May 5 is higher, and the planting time of Paza No.1 SS used in this experiment is July 25 ; the influence of planting time has an impact on the Fe content of SS; in addition, the study found that when the row spacing increases from $0.6 \mathrm{~m}$ to $1 \mathrm{~m}$, only the Fe content

Table 5. Mineral elements contents of the different parts of spaghetti squash (mg/100 $\mathrm{g}$ of fresh matter).

\begin{tabular}{|c|c|c|c|c|c|c|c|}
\hline Position & $\mathrm{K}$ & $\mathrm{Ca}$ & $\mathrm{P}$ & $\mathrm{Na}$ & $\mathrm{Fe}$ & $\mathrm{Zn}$ & $\mathrm{Se}$ \\
\hline Seed & $470 \pm 15.05^{a}$ & $35.3 \pm 1.14^{\mathrm{b}}$ & $589 \pm 1.61^{\mathrm{a}}$ & $0.419 \pm 0.0210^{\mathrm{a}}$ & $2.70 \pm 0.0950^{\mathrm{a}}$ & $5.02 \pm 0.166^{\mathrm{a}}$ & $0.0033 \pm 0.0003$ \\
\hline Pulp & $237 \pm 11.4^{\mathrm{b}}$ & $13.0 \pm 0.188^{\mathrm{d}}$ & $16.0 \pm 0.383^{c}$ & $0.260 \pm 0.0015^{\mathrm{b}}$ & $0.192 \pm 0.001^{c}$ & $0.129 \pm 0.006^{b c}$ & ND \\
\hline Flesh & $181 \pm 12.0^{c}$ & $17.3 \pm 0.0351^{c}$ & $9.95 \pm 0.145^{\mathrm{d}}$ & $0.163 \pm 0.0045^{\mathrm{d}}$ & $0.0447 \pm 0.003^{\mathrm{d}}$ & $0.0541 \pm 0.000^{c}$ & ND \\
\hline Peel & $168 \pm 5.84^{c}$ & $51.9 \pm 0.393^{\mathrm{a}}$ & $43.1 \pm 0.305^{\mathrm{b}}$ & $0.201 \pm 0.0035^{c}$ & $0.353 \pm 0.003^{\mathrm{b}}$ & $0.274 \pm 0.009^{\mathrm{b}}$ & ND \\
\hline
\end{tabular}

Note: Data are expressed as means \pm standard deviation. $\mathrm{a}, \mathrm{b}, \mathrm{c}$, and d each represent the significant difference in content of the same nutrient among the different parts of spaghetti squash $(p<0.05)$. ND: not detected. The number of three replicates used for calculation of means and standard deviation values. Ca $=\mathrm{Calcium}$; $\mathrm{P}=$ phosphorus; $\mathrm{K}=$ potassium; $\mathrm{Na}=$ sodium $; \mathrm{Fe}=$ iron; $\mathrm{Zn}=$ zinc; $\mathrm{Se}=$ Selenium . 
Table 6. The index of nutritional quality of the different parts of spaghetti squash.

\begin{tabular}{ccccccccccccccc}
\hline Position & $\mathrm{Ca}$ & $\mathrm{P}$ & $\mathrm{K}$ & $\mathrm{Na}$ & $\mathrm{Fe}$ & $\mathrm{Zn}$ & $\mathrm{V}_{\mathrm{A}}$ & $\mathrm{V}_{\mathrm{B} 1}$ & $\mathrm{~V}_{\mathrm{B} 2}$ & $\mathrm{~V}_{\mathrm{C}}$ & Cao & Pro & Fat & DF \\
\hline Seed & 33 & 6.3 & 175 & 0.21 & 134 & 373 & 0.003 & 0.88 & 0.5 & 1 & 0.09 & 2.7 & 2.3 & 8 \\
Pulp & 147 & 2 & 1072 & 1.6 & 116 & 116 & 0.01 & 11 & 1.8 & 6 & 1 & 2 & 0.5 & 2.3 \\
Flesh & 196 & 1.3 & 777 & 1 & 27 & 49 & 0.01 & 1.4 & 0.8 & 13.8 & 1.2 & 0.8 & 0.7 & 5.8 \\
Peel & 648 & 6 & 835 & 1.3 & 234 & 273 & 0.011 & 1.8 & 2.4 & 15 & 1 & 2.4 & 0.4 & 10 \\
\hline
\end{tabular}

$\mathrm{Ca}=$ Calcium; $\mathrm{P}=$ phosphorus $\mathrm{K}=$ potassium; $\mathrm{Na}=$ sodium; $\mathrm{Fe}=$ iron; $\mathrm{Zn}=$ zinc; $\mathrm{V}_{\mathrm{A}}=$ vitamin $\mathrm{A} ; \mathrm{V}_{\mathrm{B} 1}=$ vitamin $\mathrm{B} 1 ; \mathrm{V}_{\mathrm{B} 2}=$ vitamin $\mathrm{B} 2 ; \mathrm{V}_{\mathrm{C}}=$ vitamin $\mathrm{C} ; \mathrm{Cao}=$ non-fiber carbohydrate; Pro $=$ protein $; \mathrm{DF}=$ ditery fiber.

decreases. In this experiment, the spacing is $1 \times 0.6 \mathrm{~m}$, so the planting spacing of SS will not reduce the Fe content (Wadas \& Borysiak-Marciniak.,2016). Aliu et al.(2012) also showed that there was significant genetic variation in mineral composition of different genotypes of Cucurbita pepo L. The SS seed contained Se, which was not found in the other parts. Accordingly, the edible seed of SS has anti-aging functions and antitumor activity and in addition, it can also enhance human immunity (Mao et al., 2016; Luchese et al., 2020). The most abundant microelements content was found to be highest in the seed, followed by the peel, pulp, and flesh. The above findings therefore indicate that SS could be a good food source of microelements.

\subsection{INQ}

The content of one specific nutrient is not indicative of the overall quality of that nutrient in food. Therefore, it is important to perform comprehensive nutritional analyses. The INQ is primarily used to evaluate the comprehensive nutritional value of food (Xu et al., 2017). A food with an INQ of 2-6 for a specific nutrient is considered a good source of that specific nutrient, while a food with an INQ of $>6$ is considered to be an excellent source of that particular nutrient (Liu et al., 2017). For different parts of SS analyzed in this study, the INQ was calculated for $\mathrm{Ca}, \mathrm{P}, \mathrm{K}, \mathrm{Na}, \mathrm{Fe}, \mathrm{Zn}, \mathrm{V}_{\mathrm{A}}, \mathrm{V}_{\mathrm{B} 1}, \mathrm{~V}_{\mathrm{B} 2}, \mathrm{~V}_{\mathrm{C}}$, non-fiber carbohydrate, protein, fat, and dietary fiber (Table 6). The results showed that SS was a rich source of minerals necessary for human growth and development. Adequate supplementation with $\mathrm{K}$, Ca, and Fe can prevent diseases such as hypokalemia, rickets, and anemia, respectively, as well as cardiovascular diseases such as respiratory failure. In this study, all parts of SS except the seeds were excellent sources of $\mathrm{V}_{\mathrm{C}}$. Although the seed, flesh, and peel of SS were not a good source of $\mathrm{V}_{B 1}$, the INQ for $\mathrm{V}_{\mathrm{B} 1}$ in the pulp reached 11 . The INQs for protein, fat, and dietary fiber in the SS seed were also higher than those in the other three parts. These findings suggest that SS consumption can meet people's requirements for some nutritional elements that are often insufficient in other vegetables.

\section{Conclusions}

To the best of our knowledge, this is the study to investigate the major nutritional and functional components of different parts of SS, such as vitamins, amino acids, minerals, trigonelline, and tartronic acid. The findings of this study can help assess the potential of the seed, pulp, flesh and peel of SS for commercial application as nutraceuticals and for their incorporation in food formulations to improve health. In this study, it was found that the SS seed had a high content of protein, fat, dietary fiber, and amino acids as well as selenium and cystine, which were not found in the other three parts of the vegetable. The flesh of $\mathrm{SS}$ also had a high $\mathrm{V}_{\mathrm{C}}$ content, which could help eliminate the mutation of carcinogenic nitrosamines and provide an excellent anticancer effect. The low non-fiber carbohydrate and soluble sugar contents and the abundant trigonelline content of SS also make it the right food choice for patients with diabetes. The peel was packed with $\mathrm{Ca}, \mathrm{K}$, and tartronic acid, which can effectively prevent osteoporotic fractures and maintain normal nerve and muscle function.

SS could also be the preferred vegetable for weight-loss groups due to its high tartronic acid content. SS also had high $\mathrm{K}$, high $\mathrm{Ca}$, and low $\mathrm{Na}$ contents, which are especially suitable for elderly and hypertensive patients. As the seed, pulp, and peel of SS are usually discarded away, their nutrient value is wasted. Moreover, the results of this comparative nutritional analysis indicate that these unused parts may also be an important source of nutraceuticals. In this study, only the nutritional components of SS were determined and analyzed, but whether it can be processed into nutraceuticals in the future requires further investigation. In addition, any increase in the market demand and supply of SS due to an increased in it as a food and nutraceutical source, will increase interest in further investigations into its storage and processing.

\section{Acknowledgements}

This research was financially supported by the Hongcheng agricultural technology company, Sixian County, Anhui Province, China (No. K4030219015).

\section{References}

Aliu, S., Rusinovci, I., Fetahu, S., Salihu, S., \& Zogaj, R. (2012). Nutritive and mineral composition in a collection of Cucurbita pepo L. grown in Kosova. Food and Nutrition Sciences, 3(05), 634-638. http://dx.doi. org/10.4236/fns.2012.35087.

Amin, M. Z., Islam, T., Uddin, M. R., Uddin, M. J., Rahman, M. M., \& Satter, M. A. (2019). Comparative study on nutrient contents in the different parts of indigenous and hybrid varieties of pumpkin (Cucurbita maxima Linn.). Heliyon, 5(9), e02462. http://dx.doi. org/10.1016/j.heliyon.2019.e02462. PMid:31687561.

Anwar, S., Bhandari, U., Panda, B. P., Dubey, K., Khan, W., \& Ahmad, S. (2018). Trigonelline inhibits intestinal microbial metabolism of choline and its associated cardiovascular risk. Journal of Pharmaceutical and Biomedical Analysis, 159, 100-112. http://dx.doi.org/10.1016/j. jpba.2018.06.027. PMid:29980011. 
Apostol, L., Berca, L., Mosoiu, C., Badea, M., Bungau, S., Oprea, O. B., \& Cioca, G. (2018). Partially defatted pumpkin (Cucurbita maxima) seeds - a rich source of nutrients for use in food products. Revista De Chimie, 69(6), 1398-1402. http://dx.doi.org/10.37358/RC.18.6.6332.

Arnold, R., Pianta, T. J., Pussell, B. A., Endre, Z., Kiernan, M. C., \& Krishnan, A. V. (2019). Potassium control in chronic kidney disease: implications for neuromuscular function. Internal Medicine Journal, 49(7), 817-825. http://dx.doi.org/10.1111/imj.14114. PMid:30230667.

Association of Analytical Chemists - AOAC. (2000). Official methods of analysis (17th ed.). Gaithersburg, MD: AOAC International.

Beany, A. H., Stoffella, P. J., \& McCollum, G. (2003). Production and postharvest characteristics of spaghetti squash in South Florida. HortScience, 38(6), 1278.

Beany, A. H., Stoffella, P. J., Roe, N., \& Picha, D. H. (2002). Production, friut quality, and nutritional value of spaghetti squash. In J. Janick \& A. Whipkey (Eds.), Trends in new crops and new uses (pp. 445-448). Alexandria, VA: ASHS Press.

Bouis, H. (2018). Reducing mineral and vitamin deficiencies through biofortification: progress under harvestplus. In H. K. Biesalski \& R. Birner (Eds.), Hidden hunger: strategies to improve nutrition quality (Vol. 118, pp. 112-122). Basel, Switzerland: Karger Publishers. http:// dx.doi.org/10.1159/000484342.

Briffa, J. F., O’Dowd, R., Romano, T., Muhlhausler, B. S., Moritz, K. M., \& Wlodek, M. E. (2019). Reducing pup litter size alters early postnatal calcium homeostasis and programs adverse adult cardiovascular and bone health in male rats. Nutrients, 11(1), 1-19. http://dx.doi. org/10.3390/nu11010118. PMid:30626125.

Causey, J. L., Feirtag, J. M., Gallaher, D. D., Tungland, B. C., \& Slavin, J. L. (2000). Effects of dietary inulin on serum lipids, blood glucose and the gastrointestinal, environment in hypercholesterolemic men. Nutrition Research (New York, N.Y.), 20(2), 191-201. http://dx.doi. org/10.1016/S0271-5317(99)00152-9.

Cecilio, A. B. Fo., Rugeles Reyes, S. M., Ancheschi, J. A. Fo., Schiavon, A. A. Jr., \& Barbosa, J. C. (2018). Growth and accumulation of nutrients of 'Top Gun' watermelon. Científica (Jaboticabal), 46(4), 367-379. http://dx.doi.org/10.15361/1984-5529.2018v46n4p367-379.

Chang, J., Ren, H. D., Yao, X. H., Wang, K. J., Zhou, Y., \& Zhou, Z. Q. (2017). Nut Fruit Characteristics and Nutrients of Carya cathayensis Clones. Forest Research, 30, 166-173.

Chen, L., Shen, M., Ma, A., \& Han, W. L. (2018). Investigation of trace element content in the seeds, pulp, and peel of mashui oranges using microwave digestion and ICP-MS analysis. Biological Trace Element Research, 182(1), 152-158. http://dx.doi.org/10.1007/s12011-0171055-6. PMid:28620727.

Corleto, K. A., Singh, J., Jayaprakasha, G. K., \& Patil, B. S. (2019). A sensitive HPLC-FLD method combined with multivariate analysis for the determination of amino acids in L-citrulline rich vegetables. Journal of Food and Drug Analysis, 27(3), 717-728. PMid:31324287.

Croisier, E., Brown, T., \& Bauer, J. (2021). The efficacy of dietary fiber in managing gastrointestinal toxicity symptoms in patients with gynecologic cancers undergoing pelvic radiotherapy: a systematic review. Journal of the Academy of Nutrition and Dietetics, 121(2), 261-277. http://dx.doi.org/10.1016/j.jand.2020.08.077.

Danilchenko, H. (2002). Effect of growing method on the quality of pumpkins and pumpkin products. Folia Horticulturae, 14(2), 103-112.

de Boer, J., \& Aiking, H. (2019). Strategies towards healthy and sustainable protein consumption: A transition framework at the levels of diets, dishes, and dish ingredients. Food Quality and Preference, 73, 171181. http://dx.doi.org/10.1016/j.foodqual.2018.11.012.
Dogan, M. F., Yildiz, O., Arslan, S. O., \& Ulusoy, K. G. (2019). Potassium channels in vascular smooth muscle: a pathophysiological and pharmacological perspective. Fundamental \& Clinical Pharmacology, 33(5), 504-523. http://dx.doi.org/10.1111/fcp.12461. PMid:30851197.

Dorafshani, M. M., Nikravesh, M. R., Jalali, M., \& Soukhtanloo, M. (2018). Effect of drinkingwater nitrates and vitamin C on rat liver enzymes and oxidative markers. Iranian Red Crescent Medical Journal, 20(11)

Food And Agriculture Organization of The United Nations/World Health Organization - FAO/WHO 1991. Protein quality evaluations. Report of a Joint FAO/WHO Expert consultation Rome. Rome: Food and Agricultural Organization.

Gaddam, A., Galla, C., Thummisetti, S., Marikanty, R. K., Palanisamy, U. D., \& Rao, P. V. (2015). Role of fenugreek in the prevention of type 2 diabetes mellitus in prediabetes. Journal of Diabetes and Metabolic Disorders, 14(1), 74. http://dx.doi.org/10.1186/s40200-015-0208-4. PMid:26436069.

Garcia-Amezquita, L. E., Tejada-Ortigoza, V., Heredia-Olea, E., Serna-Saldívar, S. O., \& Welti-Chanes, J. (2018). Differences in the dietary fiber content of fruits and their by-products quantified by conventional and integrated AOAC official methodologies. Journal of Food Composition and Analysis, 67, 77-85. http://dx.doi. org/10.1016/j.jfca.2018.01.004.

Guo, C. J. (2020). Characteristics and high yield cultivation techniques of Sixian spaghetti squash. Anhui Agricultural Science Bulletin, 26(1), 48-49.

Han, H.-K., Min-Seung, K., Na, J.-M., Yoon, H.-N., Kim, S.-Y., Kim, S.N., Kim, J.-B., Park, H.-J., Jo, Y.-S., \& Kim, S.-Y. (2011). Quantitative changes of nutritional composition of spaghetti squash by boiling. Korean Journal of Food and Cookery Science, 27(6), 815-823.

Howard, B. V., Aragaki, A. K., Tinker, L. F., Allison, M., Hingle, M. D., Johnson, K. C., Manson, J. E., Shadyab, A. H., Shikany, J. M., Snetselaar, L. G., Thomson, C. A., Zaslavsky, O., \& Prentice, R. L. (2018). A low-fat dietary pattern and diabetes: a secondary analysis from the women's health initiative dietary modification trial. Diabetes Care, 41(4), 680-687. http://dx.doi.org/10.2337/dc17-0534. PMid:29282203.

Hu, G. L., Wang, X., Zhang, L., \& Qiu, M. H. (2019). The sources and mechanisms of bioactive ingredients in coffee. Food \& Function, 10(6), 3113-3126. http://dx.doi.org/10.1039/C9FO00288J. PMid:31166336.

Kajanus, J., Antonsson, T., Carlsson, L., Jurva, U., Pettersen, A., Sundell, J., \& Inghardt, T. (2019). Potassium channel blocking 1,2-bis(aryl) ethane-1,2-diamines active as antiarrhythmic agents. Bioorganic \& Medicinal Chemistry Letters, 29(10), 1241-1245. http://dx.doi. org/10.1016/j.bmcl.2019.03.006. PMid:30879840.

Kaur, M., Kaur, R., \& Gill, B. S. (2017). Mineral and amino acid contents of different flaxseed cultivars in relation to its selected functional properties. Journal of Food Measurement and Characterization, 11(2), 500-511. http://dx.doi.org/10.1007/s11694-016-9417-x.

Khalili, M., Alavi, M., Esmaeil-Jamaat, E., Baluchnejadmojarad, T., \& Roghani, M. (2018). Trigonelline mitigates lipopolysaccharide-induced learning and memory impairment in the rat due to its anti-oxidative and anti-inflammatory effect. International Immunopharmacology, 61, 355-362. http://dx.doi.org/10.1016/j.intimp.2018.06.019. PMid:29935483.

Kulczyński, B., \& Gramza-Michalowska, A. (2019). The profile of secondary metabolites and other bioactive compounds in cucurbita pepo L. and cucurbita moschata pumpkin cultivars. Molecules (Basel, Switzerland), 24(16), 1-22. http://dx.doi.org/10.3390/ molecules24162945. PMid:31416184.

Lebot, V., Malapa, R., \& Jung, M. (2013). Use of NIRS for the rapid prediction of total $\mathrm{N}$, minerals, sugars and starch in tropical root and 
tuber crops. New Zealand Journal of Crop and Horticultural Science, 41(3), 144-153. http://dx.doi.org/10.1080/01140671.2013.798335.

Liu, X., Mu, T. H., Sun, H. N., Zhang, M., Chen, J. W., \& Fauconnier, M. L. (2017). Comparative study of the nutritional quality of potato-wheat steamed and baked breads made with four potato flour cultivars. International Journal of Food Sciences and Nutrition, 68(2), 167-178. http://dx.doi.org/10.1080/09637486.2016.1226272. PMid:27608859.

Luchese, C., Barth, A., da Costa, G. P., Alves, D., Novo, D. L. R., Mesko, M. F., \& Wilhelm, E. A. (2020). Role of 7-chloro-4-(phenylselanyl) quinoline as an anti-aging drug fighting oxidative damage in different tissues of aged rats. Experimental Gerontology, 130, 110804. http:// dx.doi.org/10.1016/j.exger.2019.110804. PMid:31811892.

Mao, G. H., Ren, Y., Li, Q., Wu, H. Y., Jin, D., Zhao, T., Xu, C. Q., Zhang, D. H., Jia, Q. D., Bai, Y. P., Yang, L. Q., \& Wu, X. Y. (2016). Anti-tumor and immunomodulatory activity of selenium (Se)polysaccharide from Se-enriched Grifola frondosa. International Journal of Biological Macromolecules, 82, 607-613. http://dx.doi. org/10.1016/j.ijbiomac.2015.10.083. PMid:26522247.

Mohamadi, N., Sharififar, F., Pournamdari, M., \& Ansari, M. (2018). A Review on biosynthesis, analytical techniques, and pharmacological activities of trigonelline as a plant alkaloid. Journal of Dietary Supplements, 15(2), 207-222. http://dx.doi.org/10.1080/19390211 .2017.1329244. PMid:28816550.

Ntuli, N. R. (2019). Nutrient content of scarcely known wild leafy vegetables from northern KwaZulu-Natal, South Africa. South African Journal of Botany, 127, 19-24. http://dx.doi.org/10.1016/j. sajb.2019.08.033.

Okabe, T., Yakushiji, T., Shimazu, S., Saito, J., Kimura, T., Oyama, Y., Igawa, W., Ono, M., Kido, T., Ebara, S., Yamashita, K., Yamamoto, M. H., Amemiya, K., Isomura, N., \& Ochiai, M. (2018). Serum zinc concentration in patients with acute myocardial infarction in percutaneous coronary intervention era. PLoS One, 13(8), e0203074. http://dx.doi.org/10.1371/journal.pone.0203074. PMid:30161233.

Oyeyinka, B. O., \& Afolayan, A. J. (2019). Comparative evaluation of the nutritive, mineral, and antinutritive composition of Musa sinensis L. (Banana) and Musa paradisiaca L. (Plantain) fruit compartments. Plants, 8(12), 598. http://dx.doi.org/10.3390/ plants8120598. PMid:31842474.

Pan, T. T., Chyngyz, E., Sun, D. W., Paliwal, J., \& Pu, H. (2019). Pathogenetic process monitoring and early detection of pear black spot disease caused by Alternaria alternata using hyperspectral imaging. Postharvest Biology and Technology, 154, 96-104. http:// dx.doi.org/10.1016/j.postharvbio.2019.04.005.

Pravalika, K., Sarmah, D., Kaur, H., Vats, K., Saraf, J., Wanve, M., Kalia, K., Borah, A., Yavagal, D. R., Dave, K. R., \& Bhattacharya, P. (2019). Trigonelline therapy confers neuroprotection by reduced glutathione mediated myeloperoxidase expression in animal model of ischemic stroke. Life Sciences, 216, 49-58. http://dx.doi.org/10.1016/j. lfs.2018.11.014. PMid:30414429.

Septembre-Malaterre, A., Stanislas, G., Douraguia, E., \& Gonthier, M. P. (2016). Evaluation of nutritional and antioxidant properties of the tropical fruits banana, litchi, mango, papaya, passion fruit and pineapple cultivated in Reunion French Island. Food Chemistry,
212, 225-233. http://dx.doi.org/10.1016/j.foodchem.2016.05.147. PMid:27374527.

Servillo, L., Giovane, A., Casale, R., Balestrieri, M. L., Cautela, D., Paolucci, M., Siano, F., Volpe, M. G., \& Castaldo, D. (2016). Betaines and related ammonium compounds in chestnut (Castanea sativa Mill.). Food Chemistry, 196, 1301-1309. http://dx.doi.org/10.1016/j. foodchem.2015.10.070. PMid:26593620.

Sun, H., Mu, T. H., Xi, L. S., Zhang, M., \& Chen, J. W. (2014). Sweet potato (Ipomoea batatas L.) leaves as nutritional and functional foods. Food Chemistry, 156, 380-389. http://dx.doi.org/10.1016/j. foodchem.2014.01.079. PMid:24629984.

Sun, Q., Wang, N., Xu, W. H., \& Zhou, H. K. (2021). Ribes himalense as potential source of natural bioactive compounds: Nutritional, phytochemical, and antioxidant properties. Food Science \& Nutrition, 00, 1-17. http://dx.doi.org/10.1002/fsn3.2256.

Sun, Y. R., Qin, Z. W., Zhou, X. Y., \& Xin, M. (2013). The effects of different factors on cucumber tartronic acid content. Chinese Agricultural Ence Bulletin, 29(34), 85-89.

Wadas, W., \& Borysiak-Marciniak, I. (2016). Selected bionutrient contents in spaghetti squash depending on sowing date and plant spacing. Acta Scientiarum Polonorum. Hortorum Cultus, 15(1), 55-64.

Wadas, W., \& Kalinowski, K. (2010). The effect of selected agricultural factors on the yielding of spaghetti squash (Cucurbita pepo L.). Acta Scientiarum Polonorum. Hortorum Cultus, 9(2), 93-101.

Wadas, W., Mioduszewska, H., \& Kalinowski, K. (2012). Effects of selected agronomical factors on the content of health-promoting compounds in spaghetti squash (Cucurbita pepo L. subsp pepo). Folia Horticulturae, 24(1), 33-39. http://dx.doi.org/10.2478/v10245012-0004-2.

Xu, F., Hu, H. H., Dai, X. F., Liu, Q. N., Huang, Y. J., \& Zhang, H. (2017). Nutritional compositions of various potato noodles: comparative analysis. International Journal of Agricultural and Biological Engineering, 10(1), 218-225.

Xu, L. L., Li, Y. H., Dai, Z., \& Wang, Y. (2016). Research on ethanol extraction of tartronic acid in cucumber. Food Research and Development, 37(11), 93-96.

Xu, Y. Q., Wang, C., \& Cui, C. S. (2010). HPLC determination of trigonelline in pumpkin pulp. Shipin Kexue, 31(10), 209-211.

Yang, B. J., Chi, M. G., Yuan, J., Bi, W., \& Cheng, W. (2021). U.S. Patent No. 10918660B2. United States: Beijing Ruiqian Science and Technology Development Co Ltd.

Yu, E., Malik, V. S., \& Hu, F. B. (2018). Cardiovascular disease prevention by diet modification JACC health promotion series. Journal of the American College of Cardiology, 72(8), 914-926. http://dx.doi. org/10.1016/j.jacc.2018.02.085. PMid:30115231.

Zhuang, X. L. (2019). Green and efficient cultivation techniques of Sixian spaghetti squash Modern. Agricultural Science and Technology, (16), 73-74.

Zou, T. B., He, T. P., Li, H. B., Tang, H. W., \& Xia, E. Q. (2016). The structure-activity relationship of the antioxidant peptides from natural proteins. Molecules (Basel, Switzerland), 21(1), 72. http:// dx.doi.org/10.3390/molecules21010072. PMid:26771594. 